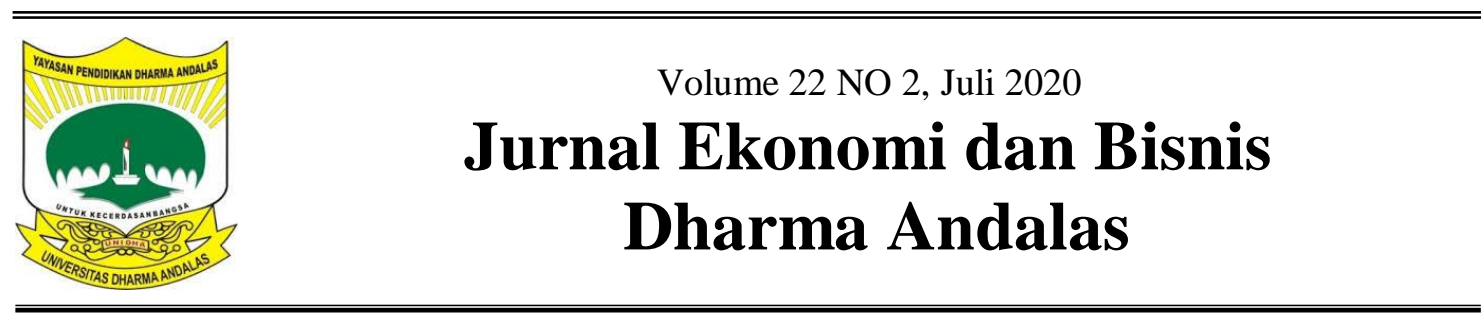

\title{
Kontribusi Dimensi Gaya Kepemimpinan Islami Pada Kinerja Guru
}

\author{
Edi Bahtiar Syam ${ }^{1}$, Poppy Nahdia Syahrani Pascawati ${ }^{2}$, Herman Sjahruddin ${ }^{3}$ \\ Sekolah Tinggi Ilmu Ekonomi Makassar Bongaya ${ }^{1,2,3}$ \\ email: herman.sjahruddin@gmail.com
}

\begin{abstract}
The practice of Islamic leadership in education becomes very important to be analyzed in creating quality education through the performance produced by teachers. This research was conducted at the State Aliyah Madrasah in Makassar City using 81 teachers as population as well as samples. The results of the multiple regression analysis provide evidence that the Islamic leadership that has been shown by the madrasa head is in very good condition, that the overall dimensions used, namely the Islamic Leadership which are honest, trustworthy, smart, fair, wise and open have been able to make a real contribution in improving teacher performance. Among the overall dimensions of Islamic leadership analyzed in this study, there is one dimension that tends to have been done well by the madrasa head, namely the sincere dimension proved unable to provide a real contribution in efforts to improve teacher performance.
\end{abstract}

Keywords: islamic leadership, teacher performance

\begin{abstract}
ABSTRAK
Praktik kepemimpinan Islami dalam dunia pendidikan menjadi sangat penting untuk dianalisis dalam menciptakan pendidikan yang berkualitas melalui kinerja yang dihasilkan guru. Penelitian ini dilakukan pada Madrasah Aliyah Negeri di Kota Makassar dengan menggunakan 81 guru sebagai populasi sekaligus sebagai sampel. Hasil analisis regresi berganda memberikan bukti bahwa kepemimpinan islami yang telah diperlihatkan kepala madrasah sudah berada dalam kondisi yang sangat baik, bahwa keseluruhan dimensi yang digunakan, yaitu Kepemimpinan Islami dimensi jujur, amanah, cerdas, adil, bijaksana dan bersikap terbuka telah mampu memberikan kontribusi yang nyata dalam meningkatkan kinerja guru. Diantara keseluruhan dimensi kepeminan islami yang dianalisis dalam penelitian ini terdapat satu dimensi yang cenderung telah dilakukan dengan baik oleh kepala madrasah, yaitu dimensi ikhlas terbukti tidak mampu memberikan kontribusi yang nyata dalam upaya peningkatan kinerja guru.
\end{abstract}

Kata Kunci : kepemimpinan islami, kinerja guru

\section{PENDAHULUAN}

Pimpinan memiliki peran yang sangat penting dalam mengarahkan dan mengendalikan pelaksanaan pekerjaan. Kebutuhan organisasi terhadap pemimpin yang memiliki gaya kepemimpinan yang juga sesuai dengan kompetisi yang dihadapi dunia pendidikan saat ini, pimpinan diharapkan mampu mengatasinya untuk menunjang upaya keberlanjutan dan kemajuan organisasi (Griffin, 2004:15). Pada dunia pendidikan, peran kepemimpinan ditunjukkan melalui kepemimpinan kepala sekolah dalam meningkatan kualitas pendidikan yang dilakukan 
dengan menyediakan dan mengawasi ketersediaan sumber daya manusia (guru) baik kualitas maupun kuantitasnya.

Kepemimpinan kepala sekolah di satuan pendidikan memiliki fungsi yang strategis untuk menentukan keberhasilan atau kegagalan program yang telah ditetapkan. Kepala sekolah memimpin, bersama dengan pendidik dan tenaga kependidikan, untuk memetakan arah ke depan pendidikan di sekolah, mengembangkan pencapaian yang diharapkan, memelihara fokus perhatian terhadap proses pengajaran dan pembelajaran dan membangun lingkungan belajar yang kondusif dan positif. Oleh karena itu, kemampuan kepemimpinan kepala sekolah dapat menjadi faktor pembeda terhadap proses pendidikan yang berlangsung di sekolah (Setiyati, 2014).

Selain kepala sekolah, guru merupakan salah satu faktor penentu tinggi dan rendahnya kualitas pendidikan, dalam hal ini guru berperan sangat penting dalam membentuk tingkah laku peserta didiknya, karena guru sebagai pendidik memikul tanggung jawab untuk membimbing dan menjadi teladan bagi peserta didiknya. Kinerja guru terlihat dari rasa tanggungjawab seorang guru dalam menjalankan amanah (tugas dan tanggung jawabya) (Djatmmiko, 2006).

Pengamatan di lapangan sering dijumpai kondisi dimana guru tidak melaksanakan proses pembelajaran secara baik dan benar berdasarkan kurikulum yang telah ditetapkan sekolah, bahkan karena adanya kedekatan personal sering terjadi pembiaran yang dilakukan kepala sekolah dan rekan guru lainnya. Pada beberapa kesempatan kondisi tersebut dapat dijumpai pada pribadi guru yang tidak tepat waktu dalam mengajar. Fakta tersebut menarik untuk diamati karena kinerja guru sangat dipengaruhi oleh kepemimpinan kepala sekolah.

Kepemimpinan Islami saat ini telah menunjukkan keandalannya dalam mengubah pandangan yang skeptis terhadap kemampuan manajerial yang dimiliki atasan dalam memimpin yang disebabkan karena adanya krisis etika dari para pemimpin (Tobroni, 2005). Studi pada kepemimpinan telah banyak dilakukan, namun demikian belum banyak yang memiliki kedalaman spiritualitas. Pada dasarnya perilaku manusia dalam perspektif spiritual quotient merupakan tarik menarik energi positif dan energi negatif. Energi positif berupa dorongan spiritual dan nilai-nilai etis religius (tauhid), sedangkan energi negatif berupa nilai-nilai material (tahghut). Energi negatif dalam perspektif individu akan melahirkan perilaku kerja yang tidak efektif dan tidak mampu mendayagunakan kompetensi yang dimiliki. Manusia pada dasarnya terdiri dari unsur material dan spiritual. Dimensi spiritual mendorong manusia untuk memahami dan menginternalisasi sifat-sifat-Nya, menjalani kehidupan sesuai dengan petunjuk-Nya dengan tujuan memperoleh ridho-Nya (Hakim, 2007).

Berdasarkan pengamatan terdapat beberapa aspek yang menjadi determinan belum baiknya kualitas pendidikan pada Madrasah Aliyah Negeri di Kota Makassar, antara lain masih tingginya pengunduran diri (resign) yang dilakukan para guru pada suatu Madrasah Aliyah yang kemudian beralih ke Madrasah Aliyah lainnya (atau pekerjaan lainnya) yang mampu memberikan nilai tambah secara ekonomis kepada para guru dan rendahnya kepedulian para guru untuk memberikan pelajaran tambahan, hal ini merupakan indikasi belum baiknya kualitas kepemimpinan kepala sekolah tempat mereka menjalankan aktivitasnya. 
Belum baiknya kepemimpinan tersebut berdasarkan pengamatan lapangan diakibatkan karena gaya kepemimpinan kepala sekolah yang menurut para guru tidak relevan dengan maksud dan tujuan pendirian madrasah yang bersifat religious (Islami). Kepala Sekolah (Madrasah) dalam menjalankan fungsinya masih mengedepankan profit oriented bukan pada kemaslahatan ummat, sehingga dalam praktiknya etika kerja yang diperlihatkan oleh beberapa guru juga tidak sesuai dengan yang seharusnya disebabkan karena adanya tekanan (pengaruh) dari pemangku kepentingan sehingga berdampak pada belum maksimalnya kinerja yang diperlihatkan oleh para guru.

Madrasah merupakan organisasi pendidikan yang sangat kompetitif, para guru yang berpengetahuan dan kompetensi tinggi (sebahagian diantaranya adalah da'i) cenderung lebih fokus pada profesinya daripada organisasinya. Guru dengan kompetensi seperti ini tidak terlalu suka diperintah, dan mereka kemungkinan hanya akan mau menuangkan bakat dan kemampuannya hanya jika mereka memang menginginkannya. Kebanyakan dari mereka lebih membutuhkan kesempatan untuk mengarahkan diri mereka sendiri, dan kurang menyukai sistem komando dan format pengawasan yang selama ini dikenal. Mereka lebih fokus pada bagaimana memperbaiki kualitas moral ummat sebagai suatu bentuk kepuasan pribadi sehingga kadang keinginan untuk mengembangkan organisasi menjadi sangat rendah. Berdasarkan observasi dan wawancara peneliti pada beberapa guru, ditemukan fenomena turnover yang terjadi dikarenakan gaya kepemimpinan. Guru pada umumnya merasa tidak puas terhadap kebijakankebijakan yang pemimpin mereka buat terkait dengan beban kerja dan kompensasi. Menurut Guru, pemimpin cenderung ingin agar para bawahannya bekerja secara produktif dan melaksanakan segala kebijakan sekolah tanpa memikirkan apakah kebijakan itu sesuai dengan kemampuan dan keinginan guru.

Timbulnya kecenderungan para Guru untuk bersifat individualistis seperti di atas berakibat pada kebutuhan organisasi terhadap pemimpin yang memiliki gaya kepemimpinan yang juga sesuai dengan kompetisi yang dihadapi dunia pendidikan Islam (Madrasah) saat ini dan mampu mengatasinya sehingga upaya keberlanjutan dan kemajuan organisasi dalam kondisi tingkat persaingan yang semakin ketat akan lebih mudah dicapai. Sehingga bukan persoalan pemimpin saja, tetapi lebih dari itu adalah bagaimana kemampuan pemimpin untuk memimpin dalam konteks lingkungan pendidikan Islam.

Filsafat hidup Islam kepemimpinan dianggap sebagai kepercayaan dan tanggung jawab yang tidak hanya bertanggung jawab pada anggota yang dipimpinnya, tetapi juga bertanggung jawab di depan Allah SWT sebagaimana tercantum dalam Al Qur'an (QS. 9 :128), bahwa Sungguh Telah datang kepadamu seorang Rasul dari kaummu sendiri, berat terasa olehnya penderitaanmu, sangat menginginkan (keimanan dan keselamatan) bagimu, amat belas kasihan lagi Penyayang terhadap orang-orang mukmin.

Makna yang dapat dijelaskan dari ayat tersebut dalam pandangan fikih politik Islam, bahwa moral yang menjadi dasar kebijakan dan tindakan pemimpin adalah kemaslahatan bangsa, dikatakan sebagai tasharruf al-imam ‘ala alra`iyyah manuthun bi almashlahah yaitu tindakan pemimpin atas rakyat terikat oleh kepentingan atau kemaslahatan umum. Dengan demikian pemimpin wajib bertindak tegas demi kebaikan bangsa, bukan kebaikan diri dan kelompoknya semata. Berdasarkan 
pada QS At-Taubah (9) ayat 128 tersebut di atas dapat dijelaskan bahwa terdapat tiga sifat (moral) kepemimpinan Nabi Muhammmad SAW menurut Hakim (2007:43), yaitu:

Pertama, azizin alaihi ma anittum (berat dirasakan oleh Nabi penderitan orang lain). Dalam bahasa modern, sifat ini disebut sense of crisis, yaitu kepekaan atas kesulitan rakyat yang ditunjukkan dengan kemampuan berempati dan simpati kepada pihakpihak yang kurang beruntung. Secara kejiwaan, empati berarti kemampuan memahami dan merasakan kesulitan orang lain. Empati dengan sendirinya mendorong simpati, yaitu dukungan, baik moral maupun material, untuk mengurangi derita orang yang mengalami kesulitan.

Kedua, harishun `alaikum (amat sangat berkeinginan agar orang lain aman dan sentosa). Dalam bahasa modern, sifat ini dinamakan sense of achievement, yaitu semangat yang mengebu-gebu agar masyarakat dan bangsa meraih kemajuan. Tugas pemimpin, antara lain, memang menumbuhkan harapan dan membuat peta jalan politik menuju cita-cita dan harapan itu.

Ketiga, raufun rahim (pengasih dan penyayang). Allah SWT adalah Tuhan Yang Maha Pengasih lagi Maha Penyayang. Nabi Muhammad SAW adalah juga pengasih dan penyayang. Orang-orang beriman wajib meneruskan kasih sayang Allah dan Rasul itu dengan mencintai dan mengasihi umat manusia. Kasih sayang (rahmah) adalah pangkal kebaikan. Tanpa kasih sayang, sulit dibayangkan seseorang bisa berbuat baik. Kata Nabi, "Orang yang tak memiliki kasih sayang, tak bisa diharap kebaikan darinya.

Ketiga moral tersebut wajib hukumnya untuk dimiliki oleh pemimpin. Karena, tanpa ketiga moral ini, seorang pemimpin, dapat dipastikan bahwa ia tidak bekerja untuk rakyat, tetapi untuk kepentingan diri, keluarga, dan kelompoknya saja. Untuk itu moral merupakan esensi utama dari seorang pemimpin. Sebagai makhluk ciptaan Allah SWT, manusia ditugaskan untuk menjadi khalifah Allah SWT (khalifatu'llah fil ardhy). Allah SWT menjadikan manusia sebagai pemimpin di muka bumi. Manusia diberi kepercayaan oleh Allah SWT sebagai pengelola dunia yang dihuninya. Berdasar konsep kekhalifahan, maka manusia dituntut memiliki kemampuan dalam menggali dan mengelola dunia, baik sumber daya alam maupun sumber daya manusia. Firman Allah dalam Al Qur'an (QS. 2 :30) yang artinya, bahwa Ingatlah ketika Tuhanmu berfirman kepada para malaikat: "Sesungguhnya $\mathrm{Aku}$ hendak menjadikan seorang khalifah di muka bumi." mereka berkata: "Mengapa Engkau hendak menjadikan (khalifah) di bumi itu orang yang akan membuat kerusakan padanya dan menumpahkan darah, padahal kami senantiasa bertasbih dengan memuji Engkau dan mensucikan Engkau?" Tuhan berfirman: "Sesungguhnya Aku mengetahui apa yang tidak kamu ketahui.

Ayat tersebut menegaskan fungsi manusia sebagai khalifah Allah SWT di muka bumi. Dalam pandangan Islam kepemimpinan merupakan amanah dan tanggung jawab yang tidak hanya dipertanggung-jawabkan kepada anggota-anggota yang dipimpinnya saja tetapi juga akan dipertanggung-jawabkan di hadapan Allah SWT. Firman Allah SWT dalam Al-Qur'an (QS. 23; 8 - 11) yang artiny, Dan orang-orang yang memelihara amanat-amanat (yang dipikulnya) dan janjinya. Dan orangorang yang memelihara sembahyangnya. Mereka Itulah orang-orang yang akan mewarisi, (yakni) yang akan mewarisi syurga Firdaus. mereka kekal di dalamnya. 
Kepemimpinan Islami merupakan proses yang terjadi dalam suatu organisasi yang saling mempengaruh secara bersama antara pemimpin dan pengikut . Para pemimpin tidak diharapkan untuk memimpin atau mempertahankan peran mereka tanpa persetujuan dari pengikut, dan pada saat yang sama, keputusan yang dibuat oleh pemimpin dipengaruhi oleh masukan dari pengikut, prosesnya dinamis dan terbuka dan tujuan utamanya adalah untuk mempertahankan kekompakan dan efektivitas organisasi (Ali, 2009).

Hasil penelitian terdahulu

membuktikan bahwa gaya kepemimpinan Islami yang diukur dengan indicator shiddiq, amanah, fathonah, tabligh dan adl berpengaruh positif dan signifikan terhadap kinerja individu (Ali, 2009; Mappamiring, 2015; Nurviza dan Usman, 2019). Hasil tersebut memperoleh bantahan dari peneliti lainnya, bahwa gaya kepemimpinan Islami tidak singnifikan pengaruhnya terhadap kinerja individu (Massara, 2013).

Kepemimpinan

Islami

merupakan kemampuan yang dimiliki oleh seorang pimpinan muslim dalam melaksanakan tugas dan tanggung jawabnya selaku pemimpin sesuai kehendak Allah SWT yang telah diberitahukan-Nya melalui Rasulullah Muhamad SAW (Hakim, 2007). Kepemimpinan dalam Islam memiliki beberapa prinsip antara lain prinsip tauhid, Asy-syura (musyawarah), al-'adl (keadilan), al burriyyah ma'a mas'uliyyah (kebebasan disertai tanggung jawab), kepastian hukum, jaminan haq al-ibad. Pemimpin Islam yang ideal harus memiliki kriteriakriteria sebagai berikut :

Kejujuran, sebab tanpa kejujuran akan terjadi penyalahgunaan wewenang dan jabatan, manipulasi terhadap rakyat atau anggota-anggota yang dipimpinnya. Allah SWT juga menegaskan dalam surah At -Taubah (QS 9 : 119) yang artinya ; Hai orang-orang yang beriman bertakwalah kepada Allah, dan hendaklah kamu bersama orang-orang yang benar.

Amanah (dapat dipercaya). Dengan amanah maka akan terhindar tindakan kolusi, korupsi dan manipulasi. Allah SWT menegaskan dalam Q.S: Alahzab (33:72) yang artinya ; Sesungguhnya kami Telah mengemukakan amanat kepada langit, bumi dan gunung-gunung, Maka semuanya enggan untuk memikul amanat itu dan mereka khawatir akan mengkhianatinya, dan dipikullah amanat itu oleh manusia. Sesungguhnya manusia itu amat zalim dan amat bodoh.

Cerdas (fathonah). Pemimpin yang cerdas akan dapat mengambil inisiatif secara cermat, tepat dan cepat, ketika menghadapi permasalahan yang terjadi dalam kepemimpinannya.

Adil, sebab jika pemimpin tidak adil maka akan memunculkan kecemburuan masyarakat yang dapat memicu kerawanan sosial, konflik dan ketegangan dalam masyarakat. Pemimpin yang ideal adalah pemimpin yang dapat membawa rakyatnya menjadi makmur dalam keadilan dan adil dalam kemakmuran. Allah SWT menegaskan dalam surah Al-Maidah (QS 5: 8 ), yang artinya ; Hai orang-orang yang beriman hendaklah kamu jadi orang-orang yang selalu menegakkan (kebenaran) Karena Allah, menjadi saksi dengan adil. dan janganlah sekali-kali kebencianmu terhadap sesuatu kaum, mendorong kamu untuk berlaku tidak adil. berlaku adillah, Karena adil itu lebih dekat kepada takwa. dan bertakwalah kepada Allah, Sesungguhnya Allah Maha mengetahui apa yang kamu kerjakan.

Bijaksana dan mempunyai sikap tanggung jawab. Kebijakan-kebijakan ataupun keputusan yang diambil oleh seorang pemimpin harus benar-benar bijaksana dan dapat dipertanggung 
jawabkan, baik secara moral maupun secara formal.

Terbuka (bersedia dikritik dan mau menerima saran dari orang lain). Sikap terbuka ini mencerminkan sifat tawadu' (rendah hati), tidak sombong. Allah SWT menegaskan pada surah AlHujurat (QS 49 :6), yang artinya; Hai orang-orang yang beriman, jika datang kepadamu orang fasik membawa suatu berita, Maka periksalah dengan teliti agar kamu tidak menimpakan suatu musibah kepada suatu kaum tanpa mengetahui keadaannya yang menyebabkan kamu menyesal atas perbuatanmu itu.

Keikhlasan, berbuat dan beramal dengan ikhlas merupakan hal yang sangat penting dalam pandangan Islam. Sebab tanpa keikhlasan amal perbuatan dalam pandangan Allah SWT akan siasia. Keikhlasan di sini tetap dalam pengertian melaksanakan amanah kepemimpinan yang sebaik-baiknya.

Dimensi kepemimpinan Islami jika dilaksankan dengan baik maka berdampak pada maksimalnya hasil kerja (kinerja) guru. Kinerja disebut juga sebagai prestasi kerja atau dalam bahasa inggris disebut dengan performance.

Pada prinsipnya ada istilah lain yang lebih menggambarkan pada prestasi dalam bahasa inggris yaitu kata "achievement". Tetapi karena kata tersebut berasal dari kata "to achieve" yang berarti mencapai, maka dalam bahasa Indonesia sering diartikan sebagai pencapaian atau apa yang dicapai (Robbins, 2006:29). Kinerja pada individu juga disebut dengan job performance, work outcome, task performance. Kinerja (performance) dapat diartikan sebagai kesuksesan di dalam melaksanakan suatu pekerjaan (Baron dan Greenberg, 1990:42). Beberapa indkator yang dapat digunakan dalam mengukur kinerja guru (Cash dan Fischer, 1987; Efendy dkk., 2017; Reynaldi dkk., 2019), yaitu :
Ketepatan Waktu merupakan kemampuan guru dalam menyelesaikan tugas dan pekerjaan dengan teliti sesuai waktu yang telah diberikan dan direncanakan, dengan ketepatan waktu dalam pelaksanaan pekerjaan sebagai guru, maka guru dapat dijadikan sebagai tauladan dari siswa-siswanya.

Kualitas Pekerjaan merupakan kemampuan guru dalam menyelesaikan tugas dengan teliti sesuai mutu pekerjaan yang direncanakan.

Kuantitas Pekerjaan merupakan kemampuan guru dalam menyelesaikan pekerjaan dibandingkan dengan target yang telah ditentukan.

\section{METODE PENELITIAN}

Jenis penelitian yang digunakan dalam penelitian ini adalah jenis penelitian kuantitatif dengan metode survey. Penelitian kuantitatif adalah jenis penelitian yang berlandaskan pada filsafat positivisme, digunakan untuk meneliti pada populasi atau sampel tertentu, teknik pengambilan sampel dilakukan secara random, pengumpulan data menggunakan instrument penelitian, analisis data bersifat kuantitatif dengan tujuan untuk menguji hipotesis yang telah ditetapkan.

Penelitian ini dilakukan pada Madrasah Aliyah Negeri di Kota Makassar. Pemilihan Madrasah Aliyah tersebut disebabkan karena jumlah guru yang dimiliki kedua Madrasah tersebut lebih banyak dibandingkan dengan Madrasah Aliyah lainnya di Kota Makassar.

Populasi dalam penelitian ini yaitu seluruh guru pada Madrasah Aliyah Negeri yang jumlahnya sebanyak 81 Guru. Teknik pengambilan sampel dilakukan dengan menggunakan teknik total sampling, sehingga jumlah sampel yang digunakan dalam penelitian ini sejumlah 81 Guru. Skala yang digunakan dalam peneltian ini menggunakan skala ordinal dengan tipe 
skala likert, skala ini digunakan untuk mengukur sikap, pendapat dan persepsi seseorang atau sekelompok tentang sesuatu hal (Sugiyono, 2010:83). Setiap pertanyaan dari variabel yang dalam kuesioner dengan mengacu pada Skala Likert, skor 1 untuk jawaban sangat buruk/rendah sampai dengan 5 untuk jawaban sangat baik/tinggi

Pembuktian hasil penelitian bersandarkan pada statistik inferensial adalah teknik statistik yang digunakan untuk menganalisis data sampel dan hasilnya diberlakukan untuk populasi, statistik ini akan cocok digunakan bila sampe diambil dari populasi yang jelas dan teknik pengambilan sampel dari populasi itu dilakukan secara random (Ghozali, 2016:170). Persamaan regresi linear berganda adalah sebagai berikut:



\section{HASIL DAN PEMBAHASAN}

Langkah awal penganalisaan data dimulai dengan menggambarkan profile responden yaitu sebagai berikut:

Tabel 1.

Deskripsi Responden

\begin{tabular}{lcc}
\hline \multicolumn{1}{c}{ Parameter } & N & \% \\
\hline$<21$ Tahun & 3 & 3.7 \\
$>$ 35 Tahun & 16 & 19.8 \\
21-25 Tahun & 18 & 22.2 \\
26-30 Tahun & 17 & 21.0 \\
$>$ 31 Tahun & 27 & 33.3 \\
\hline
\end{tabular}

\begin{tabular}{|c|c|c|}
\hline Total Berdasarkan Umur & 81 & 100.0 \\
\hline Laki-Laki & 45 & 55.6 \\
\hline Perempuan & 36 & 44.4 \\
\hline Total Berdasarkan gender & 81 & 100.0 \\
\hline$<5$ Tahun & 37 & 45.7 \\
\hline$>16$ Tahun & 13 & 16.0 \\
\hline$<15$ Tahun & 22 & 27,2 \\
\hline 6-10 Tahun & 9 & 11.1 \\
\hline $\begin{array}{l}\text { Total Berdasarkan Masa } \\
\text { Kerja }\end{array}$ & 81 & 100.0 \\
\hline S1 & 49 & 60.5 \\
\hline S2 & 32 & 39.5 \\
\hline $\begin{array}{r}\text { Total Berdasarkan } \\
\text { Pendidikan }\end{array}$ & 81 & 100.0 \\
\hline NON-ASN & 29 & 35.8 \\
\hline ASN & 52 & 64.2 \\
\hline $\begin{array}{l}\text { Total Berdasarkan Status } \\
\text { Ketenagaan }\end{array}$ & 81 & 100.0 \\
\hline
\end{tabular}

Sumber : Data diolah

Mengacu pada tingkat usia responden dicirikan dengan usia > 31 Tahun $=27$ (33,3\%), kondisi ini menjelaskan jika responden telah berada pada usia yang matang sehingga mereka dipandang mampu mengetahui dengan jelas fungsi dan tugasnya selaku guru. Jika dilihat dari gender respon yang didominasi dengan pria $=45(55,6 \%)$ maka dapat dinyatakan bahwa kemampuan kerja yang dimiliki lebih bersifat flexible sehingga diyakini jika pria memiliki kemampuan kerja lebih dibandingkan wanita yang lebih terstruktur sehingga dalam kondisi tertentu menjadi pembatas antara pria dan wanita.

Hal yang serupa pada masa kerja responden yang umumnya berada pada < 15 tahun bahwa responden telah memiliki cukup pengalaman dalam melaksanakan aktivitasnya sebagai guru. Hanya saja kondisi tersebut tidak didukung dengan pendidikan akhir yang 
dimiliki responden yang pada kenyataannya didominasi dengan strata satu sehingga menjadi kendala bagi responden dalam melakukan inovasi pembelajaran. Jika melihat pada status ketenagaan responden lebih banyak yang berstatus ASN dibandikan non-ASN sehingga diyakini disipinitas dan etos kerja mereka berada pada level yang lebih sehingga mampu meningkatkan kinerja mereka selaku guru.

Hasil pengolahan validitas data menunjukkan jika semua pernyataan dari variabel kepemimpinan Islami (dimensi) dan kinerja karyawan mempunyai nilai person correlation $=>0.30$ dan $p$-value $=<0.05$ sehingga dengan demikian dapat dikatakan bahwa seluruh pernyataan yang dipergunakan dalam penelitian ini memiliki validitas (keabsahan) dalam mengukur dimensi dan variabel sehingga dinyatakan yang layak.

Keandalan data menunjukkan jika angka-angka dari nilai cronbach's alpha pada variabel kepemimpinan transformasional, motivasi kerja dan kinerja karyawan dalam penelitian ini, semuanya menunjukkan nilai cronbach alpha > 0.60. Hal ini berarti bahwa seluruh dimensi adalah realible dan dapat disimpulkan bahwa instrument penyataan kuesioner menunjukkan keandalan dalam mengukur variabelvariabel dan telah memenuhi standar reabilitas dalam model penelitian.

Kenormalan data dari hasil pengujian Kolmogorov-Smirnov sebesar 0,063 dan p-value $0,200>0,05$ sehingga dapat disimpulkan bahwa data telah berdistribusi normal.

Tabel 2.

Normalitas

\begin{tabular}{lr}
\hline \multicolumn{1}{c}{ Parameters } & Unst. Residu \\
\hline Test Statistic & .063 \\
Asymp. Sig. (2-tailed) & $.200^{\mathrm{c}, \mathrm{d}}$ \\
\hline
\end{tabular}

Sumber : Data diolah
Hasil multikol data memberikan bukti bahwa keseluruhan dimensi memiliki nilai tolerance $<1$ dan dan nilai value influence factor $<10$, maka dapat disimpulkan bahwa tidak terjadi multikolinearitas.

Pada pengujian auto diperoleh nilai 1.5888 (dL) < 1.653 (DW) $<1.6898$ (dU) maka dapat disimpulkan tidak terjadi autokorelasi.

Pengujian keragaman data menunjukkan bahwa secara keseluruhan dimensi memiliki nilai signifikansi > 0.05 artinya tidak terjadi heteroskedastisitas yang berarti datanya homogen. Dengan demikian dapat disimpulkan bahwa data ini memenuhi uji asumsi klasik pada uji heterokedastisitas.

Hasil uji keakuratan model bertujuan untuk menjelaskan jika model yang dibangun telah memenuhi uji kesesuaian model. Dasar penerikan keputusannya adalah jika F-hit $=136,974$ $>$ F-tab $=2,021$ maka model regresi dinyatakan telah memenuhi pengujian keseuaian model.

Pengujian regresi berganda dengan memanfaatkan software SPSS Ver. 25,0 menunjukkan :

Tabel 3. t-hitung

\begin{tabular}{lccc}
\hline \multicolumn{1}{c}{ Model } & $\begin{array}{c}\text { Koefisien } \\
\text { Beta }\end{array}$ & t-hitung & p-value \\
\hline (Constant) & .573 & 6.379 & .000 \\
Jujur & .353 & 3.931 & .000 \\
Amanah & .309 & 2.872 & .006 \\
Cerdas & .622 & 5.780 & .000 \\
Adil & & & \\
Bijaksana & .289 & 2.849 & .006 \\
Terbuka & .542 & 4.149 & .000 \\
\hline Ikhlas & .231 & 1.769 & .085 \\
\hline Sulmber $:$ Data & diolah &
\end{tabular}

Sumber : Data diolah 
Hasil analisis regresi dilanjutkan dalam tahapan pemahaman pada pengujian yang telah dilakukan sehingga dapat memberikan penjelasan pada temuan penelitian:

a. Efek dimensi jujur pada kinerja guru

Kontribusi dimensi jujur pada kinerja guru dapat dibuktikan dengan nilai koefisien yang terstandarisasi (standardized coefficients) yaitu bernilai 0.573. Koefisien bertanda positif tersebut menjelaskan bahwa dimensi jujur yang diperlihatkan kepala sekolah(Madrasah) dalam memimpin cenderung baik. Dapat juga dibuktikan dengan nilai $\mathrm{t}$-hitung = $6.379>1,96$ dan $\mathrm{p}$-value $=0.000<$ 0.05 sehingga dapat dinyatakan bahwa semakin baik kejujuran yang diperlihatkan kepala madrasah, maka semakin meningkat kinerja yang dihasilkan guru dalam pelaksanaan tugas dan tanggung jawabnya.

b. Efek dimensi cerdas pada kinerja guru

Kontribusi dimensi cerdas pada kinerja guru dapat dibuktikan dengan nilai koefisien yang terstandarisasi (standardized coefficients) yaitu bernilai 0.353 . Koefisien bertanda positif tersebut menjelaskan bahwa kecerdasan yang dimiliki kepala sekolah (Madrasah) dalam memimpin cenderung baik. Dapat juga dibuktikan dengan nilai thitung $=3.931>1,96$ dan $\mathrm{p}$-value $=$ $0.000<0.05$ sehingga dapat dinyatakan bahwa semakin tinggi tingkat kecerdasan yang dimiliki kepala madrasah, maka semakin meningkat kinerja yang dihasilkan guru dalam pelaksanaan tugas dan tanggung jawabnya. Bahwa kepala madrasah memiliki kecerdasan yang tinggi sehingga dapat meningkatkan kualitas belajar mengajar guru, peyelesaian beban kerja (kuantitas) dan kehadiran guru dalam melaksakan proses pembelajaran terhadap siswa. c. Efek dimensi adil pada Kinerja guru

Kontribusi dimensi adil pada kinerja guru dapat dibuktikan dengan nilai koefisien yang terstandarisasi (standardized coefficients) yaitu bernilai 0.309. Koefisien bertanda positif tersebut menjelaskan bahwa keadilan yang diperlihatkan pemimpin dalam memimpin cenderung tinggi. Dapat juga dibuktikan dengan nilai thitung $=2.872>1,96$ dan $\mathrm{p}$-value $=$ $0.000<0.05$ sehingga dapat dinyatakan bahwa semakin tinggi penciptaan keadilan pemimpin, maka semakin meningkat kinerja yang dihasilkan guru dalam pelaksanaan tugas dan tanggung jawabnya. Bahwa kepala madrasah memiliki keadilan yang tinggi sehingga dapat meningkatkan kualitas belajar mengajar guru, peyelesaian beban kerja (kuantitas) dan kehadiran guru dalam melaksakan proses pembelajaran terhadap siswa.

d. Efek dimensi bijaksana pada Kinerja guru

Kontribusi dimensi bijaksana pada kinerja guru dapat dibuktikan dengan nilai koefisien yang terstandarisasi (standardized coefficients) yaitu bernilai 0.552 . Koefisien bertanda positif tersebut menjelaskan bahwa kebijaksanaan yang ditunjukkan sehari-hari oleh pemimpin dalam memimpin cenderung baik. Dapat juga dibuktikan dengan nilai t-hitung $=2.872>1,96$ dan $\mathrm{p}$-value $=0.000<0.05$ sehingga dapat dinyatakan bahwa semakin tinggi level kebijksanaan yang ditampilkan kepala madrasah, maka semakin meningkat kinerja yang dihasilkan guru dalam pelaksanaan tugas dan tanggung jawabnya. Bahwa kepala madrasah memiliki sikap yang sangat bijaksana menurut persepsi guru sehingga dapat meningkatkan kualitas belajar mengajar guru, peyelesaian beban kerja (kuantitas) 
dan kehadiran guru dalam melaksakan proses pembelajaran terhadap siswa.

e. Efek dimensi bersikap terbuka pada Kinerja guru

Kontribusi dimensi bersikap terbuka terhadap kinerja guru dapat dibuktikan dengan nilai koefisien yang terstandarisasi (standardized coefficients) yaitu bernilai 0.542 . Koefisien bertanda positif tersebut menjelaskan bahwa sikap keterbukaan yang ditunjukkan sehari-hari oleh kepala Madrasah dalam memimpin cenderung baik. Dapat juga dibuktikan dengan nilai t-hitung $=4.149>1,96$ dan $\mathrm{p}$-value $=0.000<0.05$ sehingga dapat dinyatakan bahwa semakin baik tinggi keterbukaan yang ditampilkan kepala madrasah, maka semakin meningkat kinerja yang dihasilkan guru dalam pelaksanaan tugas dan tanggung jawabnya. Bahwa kepala madrasah bersikap terbuka dalam menjalankan fungsi sebagai pimpinan menurut persepsi guru sehingga dapat meningkatkan kualitas belajar mengajar guru, peyelesaian beban kerja (kuantitas) dan kehadiran guru dalam melaksakan proses pembelajaran terhadap siswa.

f. Efek dimensi ikhlas pada Kinerja guru Kontribusi dimensi ikhlas pada kinerja guru dapat dibuktikan dengan nilai koefisien yang terstandarisasi (standardized coefficients) yaitu bernilai 0.231 . Koefisien bertanda positif tersebut menjelaskan bahwa keikhlasan yang ditampilkan seharihari oleh kepala sekolah dalam memimpin cenderung baik. Dapat juga dibuktikan dengan nilai $\mathrm{t}$-hitung $=$ $1.769<1,96$ dan $\mathrm{p}$-value $=0.085>$ 0.05 sehingga dapat dinyatakan bahwa semakin tinggi keikhlasan yang ditampilkan kepala madrasah, maka semakin meningkat kinerja yang dihasilkan guru dalam pelaksanaan tugas dan tanggung jawabnya namun kontribusinya tdak nyata (bermakna). Bahwa kepala madrasah bersikap ikhlas dalam menjalankan fungsi sebagai pimpinan menurut persepsi guru namun terbukti belum mampu meningkatkan kualitas belajar mengajar guru, peyelesaian beban kerja (kuantitas) dan kehadiran guru dalam melaksakan proses pembelajaran terhadap siswa.

\section{SIMPULAN}

Praktik kepemimpinan Islami dalam dunia pendidikan, seperti yang telah diperlihatkan kepala madrasah sudah berada dalam kondisi yang sangat baik, bahwa keseluruhan dimensi yang digunakan, yaitu Kepemimpinan Islami dimensi jujur, amanah, cerdas, adil, bijaksana dan bersikap terbuka telah mampu memberikan kontribusi yang nyata dalam meningkatkan kinerja guru. Diantara keseluruhan dimensi kepeminan islami yang dianalisis dalam penelitian ini terdapat satu dimensi yang cenderung telah dilakukan dengan baik oleh kepala madrasah, yaitu dimensi ikhlas terbukti tidak mampu memberikan kontribusi yang nyata dalam upaya peningkatan kinerja guru.

Kinerja yang tinggi diperlihatkan oleh guru dapat meningkat ataupun sebaliknya, sehingga disarankan kepada kepala madrasah untuk mempertahankan bahkan meningkatkan kepemimpinan Islami yang ditambikannya dalam pelaksanaan kewajibanya terutama pada dimensi keikhlasan yang dalam pelaksanaannya belum mampu meningkatkan kinerja guru.

Peneliti lanjutan diharapkan menganalisis kembali dimensi variabel kepemimpinan Islami secara menyeluruh dengan menganalisis lebih lanjut dimensi ikhlas aserta memformulasi kembali dimensi tersebut 
DAFTAR PUSTAKA

Ali, A. J. (2009). Levels of existence and motivation in Islam. Journal of Management History, 15(1), 5065

Baron \& Greenberg. (1990). Behavior in Organization Understanding and Managing The. Human Side of Work. 6th edition. USA: Prentice Hall

Cash \& Fisher. (1987). Human Resources Management. USA: Prentice Hall

Djatmiko, E. (2006). Pengaruh kepemimpinan kepala sekolah dan sarana prasarana terhadap kinerja guru smp negeri kota semarang. Fokus Ekonomi: Jurnal Ilmiah Ekonomi, 1(2).

Efendy, R., Sjahruddin, H., \& Gani, M. (2017). Praktik Motivasi Kerja dan Konsekuensinya Pada Kinerja Aparatur Sipil Negara.

Ghozali, Imam. (2016). Aplikasi Analisis Multivariete Dengan Program. IBM SPSS 23 (Edisi 8). Cetakan ke VIII. Semarang : BPFE UNDIP

Griffin, R.W. (2004), Management, 7th edition, Massachusetts: Houghton Mifflin Company

Hakim, Abdul. (2007). Kepemimpinan Islami. Uninsula

Mappamiring. P. (2015). Effect of Cultural Organization, Leadership and Motivation of Work on the Performance of Employees (Studies in Islamic Banking in Makassar). International Journal of Academic Research in Business and Social Sciences, 5(12), 139-166.

Massara, N. (2013). Pengaruh Etos Kerja Islami, Kepemimpinan Islami, Motivasi Kerja, Kompetensi Terhadap Komitmen Organisasional dan Kinerja Karyawan (Studi Pada Bank Umum Syariah Di Kota
Makassar). Universitas Muslim Indonesia, Makassar.

Nurviza, C., \& Usman, N. (2019). Pengaruh Budaya Organisasi Dan Kepemimpinan Kepala Sekolah Terhadap Kinerja Guru Pada SMA Unggul Negeri 2 Boarding School Kota Banda Aceh. Jurnal Administrasi Pendidikan: Program Pascasarjana Unsyiah, 7(1).

Reynaldi, R., Ridjal, S., \& Sjahruddin, H. (2019). The role of organizational citizenship behavior in work performance: an investigation based on hotel employee survey. European Journal of Business and Management Research, 4(6).

Robbins, Stephen. (2006). Organizational Behavior. Prentice-Hall Cliffs

Setiyati, S. (2014). Pengaruh kepemimpinan kepala sekolah, motivasi Kerja, dan budaya sekolah terhadap kinerja guru. Jurnal Pendidikan Teknologi dan Kejuruan, 22(2), 200-206.

Sugiyono. (2010). Metode Penelitian Pendidikan Pendekatan Kuantitatif, kualitatif, dan $R \& D$. Bandung: Alfabeta.

Tobroni. (2005). The Spriritual Leadership, Penerbit UMM Malang 